NJDRS

CDRD

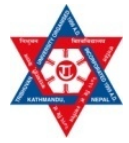

\title{
Socio Economic Status and Its Impact on School Going Domestic Child Workers in Kathmandu District
}

\author{
Surya Kumar Upadhyay \\ Santi Bidhya Griha, Lainchour, Kathmandu \\ PhD Scholar in Rural Development, Tribhuvan University \\ Email for correspondence;surya10092@gmail.com
}

\begin{abstract}
The existence of child labor is not a new phenomenon as children are still engaging in all the sector of employment. The objectives of the study was to assess economic status of school going domestic child workers (DCWs), to assess the root causes of DCWs and to examine present working condition of the DCWs. To the end, 50 DCWs studying in Santi Bidhya Griha Higher Secondary School of Kathmandu are selected as respondents. The finding shows that the cause of poverty is an essential factor to increase domestic child worker. DCWs are involving in low level households activities. Their working hour is higher than study period. Remuneration paid for DCWs is very low or not paid, behave of the owner towards DCW's is low or medium in average. The bedding and fooding situations of the DCWs are not found good. Because of that most of them are not yet satisfied with their job but compelling to continue only for their school education life. At present 15 percent of the respondents are studying in primary level, 55 percent in lower secondary level and 30 percent in secondary level. Regarding job satisfaction, some of them want to kick out their job any time but some thoughtful children want to leave after completion of grade tenth. The thoughtful children want to start their professional career in teaching; business and political sectors and few of them also want to join police and army. However, they don't have the knowledge of child labour act and child right.
\end{abstract}

Key words: Domestic child worker, poverty, socio-economic status and socio-economic impact.

\section{Introduction}

Children are the fountain a rich source of nature; they are fault less and spot less. They are the milestone of the future. So it is essential to have their all round development. But the maximum numbers of children of the developing countries are living in a structure of poverty and scarcity. Children are as beautiful as the bud of a flower, as pure as the water fall and innocent too. But in our society the proper environment is not available in which they could grow happily rather then they are ill treated and exploited by pedophiles and prosperous people. In Nepal children are facing various problems due to the backwardness, poverty, illiteracy. These are the main causes of child labor in Nepal (ILO, 1996). Domestic Child Workers are a familiar and a serious problem throughout the world, especially in South Asia. Most of the domestic child workers are girls, because they are seen to be better suited to carry out household chores. Some of them can earn a little income if they find a kind and caring family who may even educate them or help them get married. And most of them are less fortunate they live a life of hardship and misery they are often locked inside the compound, scolded, beaten and abuse (Khanal, 2001). Today children are crying for crying their urgent and basic need. The world of tomorrow will be happiest place to live, if the society well cares for mental and physical health of the children. If they are socially and economically deprived and have seen only exploited them we cannot be sure that their future is 
going to be happy and delighted. Society should encourage them with equality, freedom and dignity it can develop their satisfactory adulthood (NPC, 1998).

The children are an initial part of society and precious treasure of the world. We cannot even imagine the existence of the society unless children live around us. They are our source of hope, joy and inspiration. Hence, children are regarded as the future of the world, leader of nation for development and future star of nation. But no child can grow sufficiently without proper love, care and understanding. In each stage of childhood, a child who is innocent, vulnerable, dependent and voiceless, need the proper support of adult care, otherwise there is a chance for every child to be in danger, if they are not taken care of properly and adequately will be hampered and their future will lead towards uncertainly. Child labor is not a new phenomenon in least developing countries like Nepal.

Child labor is an emerging issue not only in urban areas but also in rural setting in Nepal. There are a substance proportion of children in several sectors of economy and there are contribution to the livelihood of households is substantial. Children are the earners of the family and their contribution remain critical. However, in a substance economy, like Nepal, children monetary contribution may be much lower against their value of work in unpaid working sectors. Poverty is regarded as the main causes of child labor around developing countries, where a family is poor; everyone has to work even extra contribution help. But many children work because of the lack of their opportunities. School might be unavailable independent or just too expensive (UNDP, 1993). Domestic Child Worker (DCW) is defined internationally as children with or without wage. DCWs are employed to perform domestic workers such as washing dishes, cooking, clearing the house, looking after young children and house activities.

The problem of child labor in Nepal is due principally to the acute poverty of people and excessive growth of population particularly in the rural areas to the people and excessive growth of population particularly in the rural areas where most people live on subsistence farming. Exploitative social relations in the villages further aggravate the problem the harsh living conditions and frequent natural disaster lead to seasonal as well as permanent migration of families and in some cases children who on their own will move from the rural to the urban areas ; child labor exists as an integral part of our labor market. No sector of labor is completely free of child labor. In Nepal many children are engaged in various kinds of labor. In about 65 different organized and unorganized labor sectors children work for their own survival and family subsistence. They work long hours with a little or no pay at all. They are deprived of basic amenities. Most of them don't have access to their families. They are vulnerable to all kinds of physical emotional and economic exploitation and abuse, more over many children in Nepal work in mast in tolerable condition like slavery and bondage. Generally child labor are those who are below fourteen years of age deprived of minimum level of facilities, working long hours, getting low wages and hindering their physical and mental development and the work done by them which affects their schooling and health. Child labor has existed everywhere. Studies (Pradhan, 1994 \& 1995) have revealed that child labor is an integral part of our labor market. From agriculture to industry, domestic service, platform, construction and transport service one can find children employed as labors. The target number of working children is found in the agricultural sector $(80 \%)$, followed by the service sector $(6 \%)$, cottage industry $(3 \%)$, industry $(2.4 \%)$, construction $(0.6 \%)$ and other informal sector $(2 \%)$. In industry, the carpet, garment and brick kilns are the 
biggest employers of child labor in Nepal. Tens of thousands of children are also found working in domestic service, restaurants, shops and bars (Pradhan 1995; as cited in Singha, 2002).

Child Labor and Rights of the Child in Nepal' author (Nembang, 1981) state that the children of every country have the right to survive and develop and the right to be protected from exploitation. It is found that the Nepalese children working in the organized and unorganized sectors have been facing many problems, which need to be analyzed not in isolation but in the broader context of socio-economic perspective and the political reality of the country. (Newang, 1998, p. 4). The casual relationship between poverty and child labor has been the subject of controversy and argument that existing child labor is not only a result but also a cause of poverty. Wherever, the actual cause and effect relationship is the commonly held view that poverty causes child labor, raises the question of whether poor children should attend school. Poverty is seen as a justification for the continuity of child labor and the attitude that is acceptable for poor children to work instead in prevalent illiteracy and family's lack of awareness is another cause of child labor. Many parents, who have had no education and skilled training for themselves, do not see need for their children to have such opportunities. Some parents see child labor as useful apprenticeship for their children to acquire knowledge and experience, which will help them as adult workers. Some parents prefer their child working to other alternatives especially when as a viable investment for future gains (Susan, 1997, p. 10). Sattur pointed out that, "borrowing at high interest rates which no viable means of repayment leads to indebtedness and children labor are the silent suffers in many cases, as labor in other people's land or in other people's houses, is taken in payment of the interest on such loans" (Sattaur, 1993, p. 7). Pant, Girish P, author of "Children Basic Need and Services in Nepal" states that meeting basic minimum needs of Nepalese Children is a great challenge. The children are yet to receive due attention. Much needs to be done to improve their condition (Pant, 1982, p. 34).

\section{Research Objectives}

- To examine working condition and socio-economic status of domestic child workers

- To assess causes and consequences of domestic child labor practices in the study area.

\section{Research Design}

The research design adopted in this study is exploratory as well as descriptive in nature. While analyzing researching issues, quantitative and qualitative data are used. Primary data is collected from purposively selected 50 school going domestic workers studying in Shanti Bidhya Griha Secondary School at Lainachaur of Kathmandu District. For that purpose, questionnaires, observation semi-structured interviews and key informants interviews techniques are applied. Similarly, secondary data are collected from school record UNICEF, Save the Children, Central library TU, CWIN office and other relevant offices. Secondary data are collected from various book and other published and unpublished documents. Respondents of semi-structured were schooling domestic child workers.

\section{Findings and Discussions}

Children are a source of joy, peace, goodwill and hope for the property of human beings at large, they were considered as manifestation. An action becomes abusive when there is abuse power, which an adult influence over of physical size, maturity and social role. Child labor is a situation when a child is forced to work or exploit for economic benefit for his own survival or to 
support his/ her family. In Nepal, children are found to be engaged in various occupations such as manufacturing carpets, the construction of roads and building, quarrying and mining as well as working as domestic servants in towns far from homes.

The study found that out of $50 \mathrm{DCWs}, 10$ percent of total of respondents are from urban areas and 90 percent are from rural areas. Most of the respondents are Hindu in religion and 22 percent are Brahimin in caste/ethnic group. In education status, all the respondents are schooling, among them 15 percent reading in primary level, 55 percent are in lower secondary level and 30 percent are reading in secondary level. The DCWS are found from periphery districts of Kathmandu. DCWs in their respective age and sex selected with more boys than girls. Out of 50 respondents 42 percent are boys and 58 percent are girls. Majority of DCWs (62\%) have their both parents together in the family. Main occupation of 78 percent of the total respondent's family is agriculture, 14 percent of the total respondents work daily labor and wages service for their survival. All of the domestic child workers have their house. Majority of the DCWs (66\%) have insufficient land to feed their family. Majority of child worker $(66 \%)$ left home due to family poverty. As remuneration, 18 percent of total respondents are paid Rs 250 per month. They are compelled to do all kinds of work such as cooking, cleaning, washing, ect. 36 percent have of the total respondents had to do 4 hours per day, 8 percent have to do 8 hours, 10 percent have to do up to 8 hours. Only 34 percent respondents get 3-5 hours per day for reading and rest 66 percent respondents get only 2 hours/ day. Similarly, 2 percent of the total respondents get different food from their owner, 24 percent of total respondents don't know about the Child Labour Act.56 percent respondents are came for DCW with those relatives. 36 percent respondents are not satisfied on their work. 12 percent want to leave the work any time, 44 percent want to leave after SLC and 44 percent respondents don't like to leave their work.

\section{Conclusion}

Therefore, the study showed that domestic child workers are more from rural area than urban, the children from economically low level and very law level are serving as a domestic child worker, most of the guardians were agent for domestic child worker, the finding shows that the cause of poverty is an essential factor, which play vital role to increase domestic child worker. The works of domestic child workers were low level activities, the finding proves that working hour is high for domestic child workers and study period is limited, remuneration paid for domestic child workers is very low or not paid, behave of the owner towards DCW's is low or medium in average, they are not in good bedding and fooding situation till now, they are satisfied for only their schooling but not in their duties, they want to leave any time from their duties, but not in their duties, they want to leave any time from their duties, but some want to leave after completion of SLC education. The study also showed that DCWs want to be a teacher, businessman; leader and police man for earn money. They don't have the Knowledge of Child Labour Act. The punishment in mistake exists in this modern time.

\section{Implications}

Child Labor should be clearly defined for legal and regulation purposes. Child Labor in domestic services and other information sector should be gradually brought under the preview of the Act. Minimum age of entry into various types of work should be fixed specially in domestic child work. Legal arrangements to deal with bounded labor problem should be introduced. 
Government should provide free education with all facilities in appropriate environment for the betterment of society. All the acts made by government should be implemented strictly on the right of child labor. Local bodies should be involved the issue of child labor on their periodic plan. The government should be given to the local bodies to monitor Domestic Child Worker's condition at work. Community surveillance system should be launched to monitor the problems of child labor. It is necessary conduct the awareness program for DCWs parents. Poverty reduction programs should be implemented to the DCW's family. DCWs should be behaved as a member of the family by the respected owner.

\section{References}

CWS (1996). Situation Analysis of Street Children in Nepal. Kathmandu: National Report.

ILO/IPE (1995). Child Labour Situation in Nepal: Pomlete CWIN, National Survey ,Governmant of Nepal

ILO (1996). Child Labour in Nepal (Volume, 2). Overview and a Proposed Plan of Action. Author.

Khanal, B. R. (2001). Child Labour Practic, Issues and Options: A Study of Kathmandu Metropolis, [Unpublished MA Thesis]. Submitted to Central Department of Economics, TU, Kirtipur.

Nembang, S. (1981). Child Labour and Rights of the Childs in Nepal, "Voice of Child Workers", (5/6), December 1981.

Omer, S. (1993). Child Labour in Nepal. Kathmandu: CWIN/ASI.

Panta, G. P. (1982). Child basic Need and Services in Nepal. Kathmandu: CWIN.

Pradhan, G. (1990). Child Labour in Nepal: a Situation Analysis. Kathmandu: CWIN.

Pradhan, G. (1992). Convention on the Right of the Child: Making it a Reality, "Voice of Child Workers", (13) January- February 1992.

Pradhan, G. (1994). The Issue of Child Rights: Commitments and Little Action, "Voice of Child Workers", (15/16), December 1994.

Pradhan, G. (2002). The State of the Right of the Child in Nepal, Kantipur Offset Press, Kathmandu.

Singha, S. (2002). A Study on Child Domestic Servant in Lalitpur. A Sociological Analysis, [Unpublished MA Thesis]. Submitted to Central Department of Sociology, TU, Kirtipur.

Sharma, P. (2004). Social Science Research Methods in Practical Use. Kathmandu: Kshitiz Publication.

Susan, C. (1997). Child Labour in South Asia: A review of the Literature. Kathmandu: UNICF.

UNDP ( 1993). The Human Development Report 1993. Kathmandu: UNDP.

Wolff, H. K. \& Pant, P. R. (2002). A Hand Book for Social Science Research and Thesis Writing. Kathmandu: Buddha Academic Publisher and Distributors. 